\title{
Risk Performance on Financial Assessment of Insurance Firms in Egypt
}

\author{
Salah Mohamed Eladly \\ Department of Business Administration, Higher Institute of Advanced Studies, Giza, Egypt
}

Received September 20, 2021; Revised November 15, 2021; Accepted December 13, 2021

\section{Cite This Paper in the following Citation Styles}

(a): [1] Salah Mohamed Eladly, "Risk Performance on Financial Assessment of Insurance Firms in Egypt," Universal Journal of Accounting and Finance, Vol. 10, No. 1, pp. 47-61, 2022. DOI: 10.13189/ujaf.2022.100106.

(b): Salah Mohamed Eladly (2022). Risk Performance on Financial Assessment of Insurance Firms in Egypt. Universal Journal of Accounting and Finance, 10(1), 47-61. DOI: 10.13189/ujaf.2022.100106.

Copyright $₫ 2022$ by authors, all rights reserved. Authors agree that this article remains permanently open access under the terms of the Creative Commons Attribution License 4.0 International License

\begin{abstract}
The subject matter of this study is the analysis of the relationship between risk assessment and firm size on financial performance. The population encompasses thirty-nine listed insurance firms in Egypt during the period 1999 - 2019, whereas a sample of nineteen insurance companies was selected. The financial assessment is a dependent variable, while the independent variable is risk assessment. This study used general linear multivariate analysis and descriptive statistics. The article is an attempt to investigate the relationship between risk assessment and firm size on financial assessment of insurance sector in Egypt. The results indicate that there is significant positive linear relationship between standard deviation of return on equity, standard deviation of return on asset, and natural logarithm of total assets with return on equity. Moreover, there is significant positive linear relationship between standard deviation of return on equity, standard deviation of return on asset and natural logarithm of total assets where on return on asset. Therefore, there is significant positive linear relationship between standard deviation of return on equity and standard deviation of return on asset on liquidity. Nevertheless, there is a negative relationship between natural logarithm of total assets.
\end{abstract}

Keywords Financial Assessment, Risk Assessment, Natural Logarithm of Total Assets

\section{Introduction}

Insurance industry, as a financial intermediary, presents two functions of economics compensation and financing in conjunction with taking risks assessing risk is a very important factor which insurance attend to achieve their financial performance.

Insurance sector, as an integral part of Egyptian economic, is heavily regulated than elsewhere in regard to liquidity constraints and investment channels. So, the regulations contributed to limited ability to maximize profitability in Egypt. However, the positive side of these regulations mitigated the side effects of the financial crisis that plagued the world economy in 2008 and coved-19 in recent years.

Previous studies on risk performance are almost rare in Egypt, while the studies on financial performance in different economic sectors have been increasingly published. So, this study as applied in insurance sector, highlights the relationship between risk performance and financial performance where financial performance represents the firm's efficiency in using their resources to build profits. The liquidity variable was selected beside profitability because of its importance in insurance industry.

\section{Literature Review}

\subsection{Insurance Industry}

Several studies were conducted to investigate the effect of risk management on financial performance in insurance industry. Arif A. Wani \& Showket A. Dar [3] research findings, by using multiple linear regression model to 
investigate relationship between risks on financial performance, indicate that there is an insignificant relationship between them, also the study determined the important factors which have an effect on financial performance such as capital management risk size of firm, solvency risk, liquidity risk volume of firm, and underwriting risk in life insurance companies in India. Also, in line with this study, Ibrahim M. Fali \& Lateef Olumide M. [8], by using linear regression model, concluded that insolvency risk has a positive significant relationship with return on asset, but there is a negative insignificant relationship between liquidity risks with return on asset of listed insurance companies in Nigeria. On the other hand, Kokobe SA\& Gemechu D [12] used correlation matrix to investigate the relationship between risk management techniques; the study findings indicated that the risk management has an influence on financial performance measured by return on equity where risk management measured by (loss preventions and control loss financing and risk avoidance) in insurance companies in Ethiopia. In consistence with the previous study, L. Paige Fields \& et al [13] by using ordinary least square analysis, conducted a comparison study on (513) companies representing (66) countries; the findings denote that risk taking measured by (capital value of leverage and capital value of solvency) has a negative relationship with liability standards index; also creditors right has negative relationship with risk taking of non-life and life insurers; but the composite insurers, investors protection and the disclosure index have negative relationship with risk taking; while for all insures, government quality has a positive relationship with performance. Dejan S. Drljača (32) presented the risk assessment matrix model which is a combination of qualitative and quantitative approaches to determine the degree of risk level and ranking the results show that these model has ability to measure risks of insurance firms (market risks, liquidity risk, default risk and counterparty), and other significant risks in insurance companies. Whereas Saleh M. Eladly [31] examined the relationship between sources allocations measured by (capital ratio and assets structure) on financial assessment measured by (ROE - ROA - liquidity), his study revealed that the relationship is significantly positive associated with sources allocations and risk performance in insurance companies in Egypt; however, the result is consistent with asymmetric information approach cited by Greenwald, Bruce and Stiglitz, Joseph E (43), concuring with the asymmetry approach. Also, J. David Cummins \& David W. Sommer (36) presented a simultaneous equation methodology based on option pricing model to investigate the relationship between capital and portfolio risk of insurance firms; they elucidated that capital has a positive effect on risk; moreover, they provided evidence that managerial incentive support in determining capital and risk in insurance industry. Yet, Richard D, MacMinn (40) article highlighted the corporate risk management in insurance industry; the findings reveal a partial synthesis of insurance and finance. Besides, it shows that investors can hedge the pure risk, also the hedging increases value and corporate account change incentives. However, risk management theory provides some indications when tools should be used. Contrary to asymmetry approach, Selim Mankai \& Aymen Belgacen (41) used simultaneous equation model to examine the relationship between capital, reinsurance and risk adjustment; they concluded that there are positive and significant relationships between control variables, performance and capital, but a negative one associated with cost of capital, while capital is positively significant associated with risk taking .Nevertheless, Yu-Luen Ma \& Yayuan Ren [30] paper investigated the relationship between insurers risk (operational performance risk) and institutional ownership on financial performance measured by (return on asset and cumulative abnormal return); the findings denote that there is a negative relationship between institutional ownership measured by (ratio of equity owned) and financial performance of insures during the financial crisis of 2008, whereas the relationship between institutional ownership with risk is positive. To test collective risk model in insurance sited by Zlata Djuric (39) The purpose of this study is to present the advantages and disadvantages of collective risk model in insurance based on stochastic process; the advantage of this model is that it indicates a wide range of modifications, modeling and simulation of events that may occur, while its disadvantage is the limited applicability in the practical business. In line with this study, Ognjen Vukovic (38) presented operation risk model and used Monte Carole method to construct operational risk model in insurance industry; the contributions of this paper are the construction of operational risk model, the application of $\mathrm{R}$ code in operational risk modelling, and the tools needed for operational risk models specializing in insurance and distribution used in operational risk models. To examine risk on efficiency, Gene C. Lai \& et al (35) used data envelopment analysis stochastic frontier, and the findings indicate that business strategy and organizational structure have a significant relationship with efficiency, where there is relationship between firm size risk taking, financial leverage and market on profitability and efficiency. Finally, in accordance with asymmetry information approach cited by Jing Ai \& et al [10], they designed enterprise risk management quality program based on linear model, found there is positive significant relationship between enterprise risk management on return on asset in property casualty insurers; nevertheless, they found an insignificant relationship between size, business line diversification, capitalization (policyholder surplus / admitted asset), commercial (total premium written in commercial line) and risky assets on return on assets. To evaluate risk management, Fei Ma (33) studied Chinese insurance firms and presented several recommendations 
that encourage insurance firms in China to abide by using of insurance resources, the control of proportion and the form structure of insurance firms, and risk management. As for Ferren Alwie\& et al (34), he used credible tail value at risk model to estimate individual and group risks, and also demonstrate numerical simulation based on health insurance claims data; however, credible TVaR provide risk measure and information of losses value located in right tail. In line with this study, Jekaterina Kuzmina \& et al. (37) used copula approach to measure portfolio's conditional risk in insurance firms, the findings indicate that approach is proper to satisfy regulatory requirements and internal risk management standards.

\subsection{Banking Sector}

Another stream of studies was directed to investigate the effect of vitality of return on equity and vitality of return on assets with financial assessment in banking sector. Alalade S. Yimka \& et al [2] used a panel least square model to examine the relationship between credit risks on financial performance in commercial banks in Nigeria, the findings show that there is a positive effect of (ratio of non-performing loans and advance / provision for loans) and (advance losses) with return on equity, whereas there is a negative impact of ratio of provision and advances to total loans and advances on return on equity. In concur with this study, Bimo A, Tejo1\& Dewi Hanggraeni [5] used panel data analysis model to investigate the relationship between financial assessment and credit risk in Indonesia commercial banks. The study concluded that the credit risk measured by non-performing loans has a significant relationship with return on equity; however, credit risk has an insignificant effect on return on assets, while there is a statistical effect of liquidity and firm size on (ROA, ROE). On the other side, Ghulam Saghir \& E. Tabassam C [7] paper revealed that credit risk has a negative significant association with financial performance, while liquidity has an insignificant relationship with return on equity; besides, the relationship between earning assets to total assets ratio and net equity to total ratio has an insignificant effect on financial performance. But Jean B. Harelimana [9] used multiple regression analysis to determine risk management factors, and investigate the relationship between risk management and financial performance; the study reveals that there is relationship between risk management measured by (liquidity risk, operation risk, credit risk and default loans) and financial performance measured by (return on assets ) in Unguka bank in Rwanda. However, the study cited by Jowhar Massoudie [11] investigated the effect of financial risk and financial assessment on commercial banks used the ordinary least square technique; the results indicated that the overall model used in this paper is highly significant, and it is found that there is relationship between credit risk, cash management, budget estimate and cash planning have a positive and significant relationship with financial performance. Lemaa B, Zeleke \& Sindhu [14] studied on Ethiopian commercial banks. They find there is a statistical effect of net interest margin capital adequacy ratio, firm size and non-performing loans on return on asset. However, loans to deposit ratio, exchange rate, inflation rate have an insignificant effect on return on asset. Regarding to return on equity, it has a significant relationship with non-performing loans, loans loss provision ratio and capital adequacy ratio, but has an insignificant relationship with loans to deposit ratio, exchange rate ratio and inflation rate. Leonora H. Rudhani \& Driton Balaj [15], with different variables, but in line with the previous results, the researchers used linear regression analysis to investigate the relationship between liquidity risks measured by (current asset to total asset, liquid liability and loans deposit) on Return on Equity and Return on Asset as independent variable to measure financial assessment. The findings elucidate that liquidity risk is associated with financial assessment in Kosovo commercial banks. In consistence with this result, Nasratullah Noori [17] analyzed risk practice on Malaysian commercial banks, and the conclusions of his study indicate that credit risk and market risk have a significant impact on financial performance; however, the interest rate and liquidity risk have an insignificant impact on financial performance. With different variables to measure risk management, Olayinka ERIN\& et al [19] adopted panel data analysis to investigate the impact of risk governance measured by (board risk committee _ size /enterprise risk management_index/ chief risk officer presence) on financial performance measured by (return on asset); the findings indicate that chief risk officer presence, enterprise risk management and board risk management _ index have a positive and significant effect on return on asset, but board risk _ size has a negative relationship with return on asset in Nigerian financial sector. On the contrary of asymmetry information approach, Peter Karugu Kahihu \& et al [20] findings denote that risk measured by (interest rate and financial leverage) have a positive statistical effect of return on equity, while another risk like foreign exchange has a negative statistical association with financial assessment, but the risk of inflation has an insignificant relationship with financial performance microfinance institutions in Kenya. Besides, Ramazan Ekinci1\& Gulden Poyraz [21] study findings of Turkish deposit banks denote that the relationship between credit risk measured by (non-performing loans), and financial assessment measured by (return on asset and return on equity) is a negative relationship. In consistence with asymmetry information approach, Ravi Prakash Sharma P. [22] paper revealed that risk management measured by (default rate and capital adequacy) have a significant association with return on asset, while cost per loans asset has an insignificant relationship with return on asset of the commercial banks in Nepal. Nevertheless, contrary to 
asymmetry information theory, Robert Mironga Siriba [23] adopted the multiple regression model to investigate the impact of credit risk on financial performance; the study findings denote that non-performing loans and loss provision have an insignificant relationship with bank profitability, but the relationship between loans and advances has a significant effect on bank profitability of commercial bank in Kenya. Also, Samuel Gameli Gadzo \& et al. [24] research elucidate that operational risk, which is measured by (banks leverage and portfolio concentration), has a negative statistical effect on financial assessment, and credit risk has a statistically negative relationship with financial performance. Besides, Suleiman A. S. Aruwa \& Abdullahi O. Musa [25] study investigated the relationship between risk components on the financial performance; the study infers that operational and interest rate have a negative relationship with financial performance measured by (return on asset), but credit risk, measured by (non-performing loans ratio), has a negative association with financial performance of Deposit Money Banks in Nigeria. In line with theory of asymmetry information, Walter Gontarek \& Yacine Belghitar [28] research results found that board-level risk appetite has a positive significant relationship with performance in bank holding companies and risk. The added value of this study is the identifying of the significance of risk governance practice upon the bank performance and risk taking in US banks. On another hand, to evaluate bank performance, Yu-Chuan Chen \& et al [29] in his article presented data envelopment analysis (DEA) model to evaluate bank performance; the empirical findings of this paper showed that (DEA) model estimates an efficiency of bank holding companies, and by using data envelopment analysis as a technique to evaluate the financial performance on average financial holding companies banks a better performance is attained in different businesses. Besides, data envelopment analysis model is comparatively strictly less than DMUs in efficiency.

\subsection{Other Sectors}

Other evidences to analyse the relationship between risk assessment and financial performance are cited by Ahmad Abdel Rahim\& et al [1] who used multi regression analysis to investigate the impact of liquidity risk and solvency on financial performance measured by (return on asset and earning per share); the findings indicated that the financial assessment is a statistically associated with size, liquidity and solvency of Jordanian manufacturing firms on Amman Stock Exchange. Recently, Claudia Champagne \& et al. [6] used conditional probability model to evaluate the impact of pension fund freeze on return and risk. It was found that there is an insignificant relationship between pension fund freeze on systematic risk, but significantly reduced short-term residual risk.
However, Nicoleta B. -Misu \& et al [18] adopted panel vector autoregressive model to analyze the impact of risk factors on financial performance in European firms; the study revealed that liquidity financial leverage and productivity have a positive effect on financial assessment (ROE and ROA), while asset turnover and solvency have a statistically significant and positive relationship with return on equity, but the productivity has a negative effect on return on asset during crisis. However, on the contrary of the theory, Michael Adusei [16] presented a model to examine the impact of liquidity risk on financial performance in (73) countries; the study findings indicate that liquidity risk and credit risk have negative association with financial performance. However, size, leverage, financial development, political stability and government effectiveness have a positive relationship with financial performance which measured by (operating revenue / financial expenses +loans loss provision expenses + operating expenses). According to Sylvester Senyo Horvey \& Jacob Ankamah [26], the study results elucidate that enterprise risk management has a positive and statistically significant associated association with return on equity, return on asset and Tobin Q as dependent variables measured financial assessment of both financial and non-financial firms in Ghana; regarding control variables, firm size and efficiency have a negative association with return on equity and Tobin Q, although efficiency was insignificant but ownership has a positive relationship with financial performance of both financial firms and non-financial firm. As for Thitima Chaiyakul [27], who used multiple regression analysis, the research results denote that bankruptcy measured by (Z-score) and the size of firm positively affect return on equity, return on asset and Tobin Q, while liquidity and capital structure have a statistically significant relationship with financial performance, inflation has an insignificant relationship with financial performance in firms listed on Stock Exchange of Thailand. On the other hand, Bimbin P. Chepkemoi, Steve Ndung's \& Julius Kahuthia [4] study reveals indicated that financial leverage has a significant positive relationship with financial performance of non-bank financial institutes in Kenya. Moreover, the results show that the interest risk has a strong effect on financial performance by using Hausman and LM tests.

\section{Methodology and Variables Description}

The subject matter of this study is the analysis of the relationship between risk assessment and firm size on financial performance, wherefore this article used general linear multivariate analysis and descriptive statistics to analyze the relationship between the study variables consistent with Walter Gontarek \& Yacine Belghitar [28] 
They used the multivariate analysis and descriptive statistic. The main objective of paper is to examine the relationship between risk performances on financial performance of insurance sector in Egypt. This part provides the method used in empirical investigation, the data collected form financial reporting (balance sheets income statements) which are issued by the Financial Regulatory Authority in Egypt over the period 1999- 2019. However, the sample of this article include nineteen Egyptian insurance companies which were selected based on availability of data during the study period

\subsection{Variables Development and Measurement}

Most of prior studies used Return on Equity and Return on Asset to measure financial assessment as sited on Sylvester Senyo Horvey \& Jacob Ankamah [26], Lemaa B, Zeleke \& Sindhu [14], Thitima Chaiyakul [29], Samuel Gameli Gadzo \& et al [22] and Ramazan Ekincil\& Gulden Poyraz [19] but this study measured financial performance by ROE, ROA and liquidity

\subsection{Risk Performance Measurement}

Standard deviation of return on equity and standard deviation of return on asset are measured financial assessment, as stated in Yu-Luen Ma \& Yayuan Ren [30] and Samuel Gameli Gadzo \& et al [24]

\subsection{Model}

This paper includes three dependent variables: return on equity, return on asset and liquidity

Where independent variables are

- Financial risk measured by Standard deviation of return on equity $\left(\mathrm{X}_{1}\right)$

- Operating risk measured by standard deviation of return on assets $\left(\mathrm{X}_{2}\right)$

- Firm size measured by Natural of logarithm of total assets $\left(\mathrm{X}_{3}\right)$

$$
\begin{gathered}
\mathrm{ROE}=\beta_{0}-\beta_{1} \mathrm{SD} \mathrm{X}_{1}-\beta_{2} \mathrm{SD} \mathrm{X}_{2}-\beta \operatorname{Ln} \mathrm{X}_{3} \\
\mathrm{ROA}=\beta_{0}-\beta_{1} \mathrm{SD} \mathrm{Xi}^{-} \beta_{2} \mathrm{SD} \mathrm{X}_{2}-\beta \operatorname{Ln} \mathrm{X}_{3} \\
\mathrm{~L}=\beta_{0}-\beta_{1} \mathrm{SD} \mathrm{X}_{1}-\beta_{2} \mathrm{SDX}_{2}-\beta \operatorname{Ln} \mathrm{X}_{3} \\
\mathrm{~L}=\text { liquidity }
\end{gathered}
$$

$\begin{array}{ccc}\begin{array}{c}\text { Risk assessment } \\ \text { variables }\end{array} & \text { Abbreviation } & \begin{array}{c}\text { How to } \\ \text { calculate the } \\ \text { variables }\end{array} \\ \begin{array}{c}\text { Standard } \\ \text { deviation of }\end{array} & \text { SD ROE } & \sqrt{\frac{\left(R O E-(R O E)^{-}\right)^{2}}{N-1}} \\ \text { return on equity } & & \text { SD of ROA }= \\ \begin{array}{c}\text { Standard } \\ \text { deviation of }\end{array} & \text { SD ROA } & \sqrt{\frac{\left(R O A-(R O A)^{-}\right)^{2}}{N-1}} \\ \text { return on asset } & & \sqrt{ }\end{array}$

Financial performance variables

$$
\text { ROE }=\text { Profits / Equity }
$$

$\mathrm{L}=$ Short Term Assets $($ Cash + Deposit + S. T. Loans + Treasure Bills) / Total Assets

$\mathrm{ROA}=($ Earnings before interest and tax $) /$ Total Assets

Control variable

Firm size $=$ Natural logarithm of total asset $\left(\operatorname{Ln} X_{3}\right)$

\section{Hypothesis}

To analyse the relationship between risk performance and firm size on financial performance, this paper formulated the following null hypothesis.

1. Standard deviation of return on equity has no statistically impact on financial assessment of insurance firms in Egypt which is measured by (Return on Equity and Return on Asset)

2. Standard deviation of return on asset has a statistically influence of financial assessment of insurance firms in Egypt measured by return on equity and return on asset

3. Firm size has no statistically influence of financial assessment of insurance firms in Egypt

\section{Analysis and Empirical Results}

This part presents an analytical and empirical results of the multivariate regression model that are tested to examine the relationship between risk assessment measured by standard deviation of return on equity and standard deviation of return on assets with financial performance measured by return on equity, return on assets and liquidity, firstly to test the normality distribution. This paper used Jarque-Bera test of research variables, second multivariate model and associated tests. 
Table 1. The summary of Descriptive statistics

\begin{tabular}{|c|c|c|c|c|c|c|c|c|c|c|}
\hline Constructs & Mean & Median & Maximum & Minimum & Std. Dev. & Skewness & Kurtosis & Jarque-Bera & Probability & Observations \\
\hline $\begin{array}{c}\text { Return on } \\
\text { equity }\end{array}$ & 0.141387 & 0.139345 & 0.507055 & -0.240730 & 0.147195 & 0.097829 & 2.924681 & 0.730745 & 0.693938 & 399 \\
\hline Return on asset & 0.031490 & 0.029635 & 0.094744 & -0.034713 & 0.025771 & 0.103827 & 2.785590 & 1.481153 & 0.476839 & 399 \\
\hline Liquidity & 0.075641 & 0.055424 & 0.259331 & -0.123388 & 0.067471 & 0.665255 & 2.929317 & 29.51362 & $0.001 * * *$ & 399 \\
\hline $\begin{array}{c}\text { Standard } \\
\text { deviation of } \\
\text { ROE }\end{array}$ & 0.015071 & 0.012385 & 0.045481 & 4.67E-05 & 0.011002 & 0.761013 & 2.702422 & 39.78458 & $0.001 * * *$ & 361 \\
\hline $\begin{array}{c}\text { Standard } \\
\text { deviation of } \\
\text { ROA }\end{array}$ & 0.055933 & 0.047164 & 0.159188 & 0.000747 & 0.039497 & 0.708424 & 2.702375 & 34.67197 & $0.001 * * *$ & 361 \\
\hline $\begin{array}{c}\text { Natural } \\
\text { logarithm of } \\
\text { Total Asset }\end{array}$ & 13.17246 & 13.09940 & 16.78653 & 9.422380 & 1.537752 & 0.260876 & 2.731510 & 5.724175 & 0.057149 & 397 \\
\hline
\end{tabular}

*** P value is $\geq(0.001)$ 


\subsection{The Values of Jarque-Bera Test}

Form figures shown in table (1), it elucidated Mean on the average (.0639044), Median on t average (2.07606), Standard deviation on the average (0.2572), Skewness on the average (3.1871) and Kurtosis on the average (0.54888) and Jarque-Bera on the average (18.601). The figures shown in the table explain descriptive statistics for risk assessment as independent variables and financial assessment as dependent variables

\subsection{Univariate Detection}

Values of both lower quartile $\mathrm{Q}_{1}$ and upper quartile $\mathrm{Q}_{3}$ are calculated. Then, the inter quartile range IQR $=\mathrm{Q}_{3^{-}}$ $\mathrm{Q}_{1}$ is computed and finally the values less than $\left(\mathrm{Q}_{1}-1.5 \mathrm{IQR}\right)$ and those higher than $\left(\mathrm{Q}_{3}+1.5 \mathrm{IQR}\right)$ are excluded. The presence of some outliers and extremes for each variable separately is identified; then those outliers are omitted. based on Box-and-Whisker Plots and by using transform command, missing values linear interpolation are replaced to complete these missing values through the statistical program

\subsection{Multivariate Detection}

By using the Mahalanobis $\mathrm{D}^{2}$ measure, the relationship between two and more variables is analyzed, which often uses multivariate analyses, a multivariate evaluation of each observation across a group of proxies.

From table above outputs, it reveals that the normality distribution of return on equity $\mathrm{Y}_{1}$, and return on asset $\mathrm{Y}_{2}$ by using the Jarque-Bera test at a significant level $\leq(0.05)$. On the other hand the research variables in terms of liquidity $\mathrm{Y}_{3}$, STROE $\mathrm{x}_{1}$, and ST ROA $\mathrm{X}_{2}$ are not normally distributed, since the significant of Jarque-Bera statistic is greater than $(0.05)$.

The coefficient of Pearson skewness for all research variables is $\leq(1)$, which indicates that the data are insignificantly skewed.

\subsection{Group Unit Root Test}

The covariance is calculated for return on equity $\mathrm{Y}_{1}$ return on asset $Y_{2}$, liquidity $Y_{3}$, liquidity $y_{3}$ as dependent variables where independent variables, (X1) standard deviation of return on equity, $\mathrm{X}_{2}$ standard deviation of return on asset and $\left(\mathrm{X}_{3}\right)$ firm size through the following statistical techniques: Augmented Dickey-Fuller (ADF), Philips-Perrron (PP), and Im, Pesaran and Shin W-stat (IPSW).The covariance is computed as follows.

Output from table (2) denotes that stationary of the time series of the return on equity $\mathrm{Y}_{1}$, return on asset $\mathrm{Y}_{2}$, liquidity $\left(\mathrm{Y}_{3}\right)$, standard deviation of return on equity $\left(\mathrm{X}_{1}\right)$, standard deviation of return on asset $\mathrm{X}_{2}$ and natural logarithm of total assets $\mathrm{LNX}_{3}$ at level $1 \sim(0)$ based on the constant level, through the following criteria: LLC, IPSW, PP, and ADF, at $\rho \geq(0.001)$.

Table 2. the test of Group unit root for study variables from 1999 to 2019

\begin{tabular}{|c|c|c|c|c|}
\hline \multirow[b]{2}{*}{ Method } & \multirow[b]{2}{*}{ Statistic } & \multicolumn{3}{|c|}{ Cross- } \\
\hline & & Prob.** & Sections & Obs \\
\hline \multicolumn{5}{|c|}{ Null: Unit root (assumes common unit root process) } \\
\hline Levin, Lin \& Chu $t^{*}$ & -11.9254 & 0.0000 & 5 & 1982 \\
\hline \multicolumn{5}{|c|}{ Null: Unit root (assumes individual unit root process) } \\
\hline Im, Pesaran and Shin W-stat & -14.5945 & 0.0000 & 5 & 1982 \\
\hline ADF - Fisher Chi-square & 229.555 & 0.0000 & 5 & 1982 \\
\hline PP - Fisher Chi-square & 306.462 & 0.0000 & 5 & 1986 \\
\hline
\end{tabular}

*** $\mathrm{P}$ value is $\geq(0.001)$. 


\subsection{Co-integrating Equation Model}

To test the existence of long-run equilibrium relationship between non-stationary time series variables in terms of ROE $\left(\mathrm{Y}_{1}\right)$, ROA $\left(\mathrm{Y}_{2}\right)$, liquidity $\left(\mathrm{Y}_{3}\right)$, ST ROE $\left(\mathrm{X}_{1}\right)$, and $\operatorname{STROA}\left(\mathrm{X}_{2}\right)$, this study used Engle-Granger Co-integration test as follows:

Table 3. Co integrating Model for the study variables

\begin{tabular}{ccccc}
\hline Variables & tau-statistic & Prob. $^{*}$ & z-statistic & Prob.* \\
\hline $\mathrm{Y}_{1}$ & -7.429426 & $0.001 * * *$ & -110.3400 & $0.001 * * *$ \\
$\mathrm{Y}_{2}$ & -8.441604 & $0.001 * * *$ & -121.2173 & $0.001 * * *$ \\
$\mathrm{Y}_{3}$ & -7.924797 & $0.001 * * *$ & -123.2739 & $0.001 * * *$ \\
$\mathrm{X}_{1}$ & -8.629023 & $0.001 * * *$ & -125.6120 & $0.001 * * *$ \\
$\mathrm{X}_{2}$ & -8.825419 & $0.001 * * *$ & -128.8063 & $0.001 * * *$ \\
$\mathrm{Lnx}_{3}$ & -5.661452 & $0.001 * * *$ & -56.90290 & $0.001 * * *$ \\
\hline
\end{tabular}

*** $\mathrm{P}$ value is $\geq(0.001)$.

Based on the results in Table (3), it can be revealed long-term equilibrium relationships among $\left(\mathrm{Y}_{1}, \mathrm{Y}_{2}, \mathrm{Y}_{3}\right)$ as dependent variables and $\left(\mathrm{X}_{1}, \mathrm{X}_{2}, \ln \mathrm{X}_{3}\right)$ as independent variables during the study period, due to the Tau-statistic, and $z$-statistic, at a significant $\geq(0.001)$

\subsection{The Correlation Matrix}

Output from table (4) reveals that there is a significant positive linear association between dependent variables
$\mathrm{Y}_{1},\left(\mathrm{Y}_{2}\right)$, and $\left(\mathrm{Y}_{3}\right)$ with $\left(\mathrm{X}_{1}\right), \mathrm{X}_{2}$ and $\ln \mathrm{x}_{3}$, as independent variables at a Significant level less than $(0.05)$

\subsection{GLM Multivariate Analysis}

This presents a general linear model to test of variance for more than one dependent variable by factor covariates one or more. The process of GLM by dividing the population into groups. This model tests null hypotheses regarding to influence of factor variables on the means of various groupings of a joint distribution of dependent variables. The study examined interaction between variables and the impact of individual factors. Besides, the influence of interactions between covariate and covariates with factors. Variables are specified as covariates based on regression analysis.

Table (5), it reports that:

- By using multivariate tests, it is indicated that the overall effect of the covariates related to $\mathrm{x}_{1}, \mathrm{x}_{2}, \ln \mathrm{x}_{3}$, on the dependent variables related to the $\mathrm{y}_{1}, \mathrm{y}_{2}$, and $\mathrm{y}_{3}$, at a significant level less than (0.001).

- The partial eta squared of the covariate variables in terms of $x_{1}, x_{2}, \ln x_{3}$ and the interactions between $x 1$ $\mathrm{x}_{2}$ and $\ln \mathrm{x}_{2}$ account for (0.057-0.212-0.210-0.013) of the variation in the total dependent variables, i.e., from the medium effect to large effect, finally to small effect.

Table 4. The matrix of Pearson correlation to test a significant linear correlation between the constructs of both independent and dependent variables

\begin{tabular}{|c|c|c|c|c|c|}
\hline Constructs & $\begin{array}{l}\text { Return on equity } \\
\qquad\left(Y_{1}\right)\end{array}$ & $\begin{array}{c}\text { Return on asset } \\
\qquad\left(\mathrm{Y}_{2}\right)\end{array}$ & Liquidity $\left(\mathbf{Y}_{3}\right)$ & $\begin{array}{c}\text { Standard } \\
\text { deviation of ROE } \\
\mathrm{X}_{1} \\
\end{array}$ & $\begin{array}{c}\text { Standard } \\
\text { deviation of ROA } \\
\left(\mathrm{X}_{2}\right) \\
\end{array}$ \\
\hline $\mathrm{ROE} \mathrm{Y}_{1}$ & 1 & & & & \\
\hline $\mathrm{ROA} \mathrm{Y}_{2}$ & $0.633 * * *$ & 1 & & & \\
\hline $\mathrm{L}\left(\mathrm{Y}_{3}\right)$ & -0.0390 & -0.048 & 1 & & \\
\hline $\operatorname{STD} \operatorname{ROE}\left(\mathrm{X}_{1}\right)$ & $0.349 * * *$ & $0.418 * * *$ & $0.146^{* *}$ & 1 & \\
\hline $\operatorname{STD} \operatorname{ROA}\left(\mathrm{X}_{2}\right)$ & $0.671 * * *$ & $0.482 * * *$ & $0.115^{*}$ & $0.555 * * *$ & 1 \\
\hline $\operatorname{Lnx}_{3}$ & $0.375^{* * *}$ & $0.169 * * *$ & $-0.175 * * *$ & $-0.245^{* * *}$ & 0.082 \\
\hline
\end{tabular}

$* * * \mathrm{P}$ value is $\geq(0.001)$. ** Probability at $\geq(0.01)$. * Probability at $\geq(0.05)$. 
Table 5. Multivariate tests in terms of Pillai's Trace, Wilks' Lambda, Hotelling's Trace and Roy's Largest Root

Multivariate Tests

\begin{tabular}{|c|c|c|c|c|c|c|c|}
\hline Effect & & Value & $\mathbf{F}$ & Hypothesis df & Error df & Sig. & $\begin{array}{c}\text { Partial Eta } \\
\text { Squared }\end{array}$ \\
\hline \multirow[t]{4}{*}{ Intercept } & Pillai's Trace & .225 & $37.635^{\mathrm{a}}$ & 3.000 & 390.000 & .000 & .225 \\
\hline & Wilk's Lambda & .775 & $37.635^{\mathrm{a}}$ & 3.000 & 390.000 & .000 & .225 \\
\hline & Hotelling's Trace & .289 & $37.635^{\mathrm{a}}$ & 3.000 & 390.000 & .000 & .225 \\
\hline & Roy's Largest Root & .289 & $37.635^{\mathrm{a}}$ & 3.000 & 390.000 & .000 & .225 \\
\hline \multirow[t]{4}{*}{$\mathrm{x}_{1}$} & Pillai’s Trace & .057 & $7.913^{\mathrm{a}}$ & 3.000 & 390.000 & .000 & .057 \\
\hline & Wilk's Lambda & .943 & $7.913^{\mathrm{a}}$ & 3.000 & 390.000 & .000 & .057 \\
\hline & Hotelling's Trace & .061 & $7.913^{\mathrm{a}}$ & 3.000 & 390.000 & .000 & .057 \\
\hline & Roy's Largest Root & .061 & $7.913^{\mathrm{a}}$ & 3.000 & 390.000 & .000 & .057 \\
\hline \multirow[t]{4}{*}{$\mathrm{x}_{2}$} & Pillai's Trace & .212 & $35.051^{\mathrm{a}}$ & 3.000 & 390.000 & .000 & .212 \\
\hline & Wilk's Lambda & .788 & $35.051^{\mathrm{a}}$ & 3.000 & 390.000 & .000 & .212 \\
\hline & Hotelling's Trace & .270 & $35.051^{\mathrm{a}}$ & 3.000 & 390.000 & .000 & .212 \\
\hline & Roy's Largest Root & .061 & $35.051^{\mathrm{a}}$ & 3.000 & 390.000 & .000 & .212 \\
\hline \multirow[t]{4}{*}{$\operatorname{In} x 3$} & Pillai’s Trace & .210 & $34.510^{\mathrm{a}}$ & 3.000 & 390.000 & .000 & .210 \\
\hline & Wilk's Lambda & .790 & $34.510^{\mathrm{a}}$ & 3.000 & 390.000 & .000 & .210 \\
\hline & Hotelling's Trace & .265 & $34.510^{\mathrm{a}}$ & 3.000 & 390.000 & .000 & .210 \\
\hline & Roy's Largest Root & .265 & $34.510^{\mathrm{a}}$ & 3.000 & 390.000 & .000 & .210 \\
\hline \multirow[t]{4}{*}{$\mathrm{x}_{1} * \mathrm{x}_{2} * \operatorname{In} \mathrm{x}_{3}$} & Pillai's Trace & .013 & $1.717^{\mathrm{a}}$ & 3.000 & 390.000 & .163 & .013 \\
\hline & Wilk's Lambda & .987 & $1.717^{\mathrm{a}}$ & 3.000 & 390.000 & .163 & .013 \\
\hline & Hotelling's Trace & .013 & $1.717^{\mathrm{a}}$ & 3.000 & 390.000 & .163 & .013 \\
\hline & Roy's Largest Root & .013 & $1.717^{\mathrm{a}}$ & 3.000 & 390.000 & .163 & .013 \\
\hline
\end{tabular}

Table (5), it reports that:

- By using multivariate tests, the overall effect of the covariates related to $\mathrm{x}_{1}, \mathrm{x}_{2}, \ln \mathrm{n}_{3}$, on the dependent variables related to the $\mathrm{y}_{1}, \mathrm{y}_{2}$, and $\mathrm{y}_{3}$, at a significant level less than $(0.001)$.

- The partial eta squared of the covariate variables in terms of $\mathrm{x}_{1}, \mathrm{x}_{2}, \ln \mathrm{x}_{3}$ and the interactions between $\mathrm{x}_{1} \mathrm{x}_{2}$ and $\ln \mathrm{x}_{2}$ account for (0.057-0.212-0.210-0.013) of the variation in the total dependent variables, i.e., from the medium effect to large effect, finally to small effect. 
Table 6. Tests of between - subject's effects

\begin{tabular}{|c|c|c|c|c|c|c|c|}
\hline Source & Dependent Variable & $\begin{array}{c}\text { Type III } \\
\text { Sum of } \\
\text { Squares }\end{array}$ & Df & Mean Square & $\mathbf{F}$ & Sig. & $\begin{array}{l}\text { Partial Eta } \\
\text { Squared }\end{array}$ \\
\hline \multirow[t]{3}{*}{ Corrected Model } & $\mathrm{y}_{1}$ & $4.814^{\mathrm{a}}$ & 4 & 1.206 & 126.962 & .000 & .564 \\
\hline & $\mathrm{y}_{2}$ & $.081^{\mathrm{b}}$ & 4 & .020 & 43.863 & .000 & .309 \\
\hline & $\mathrm{y}_{3}$ & $.089^{\mathrm{c}}$ & 4 & .022 & & .001 & .049 \\
\hline \multirow[t]{3}{*}{ Intercept } & $\mathrm{y}_{1}$ & .913 & 1 & .913 & 96.084 & .000 & .197 \\
\hline & $\mathrm{y}_{2}$ & .007 & 1 & .007 & 15.271 & .000 & .037 \\
\hline & $\mathrm{y}_{3}$ & .109 & 1 & .109 & 24.883 & .000 & .060 \\
\hline \multirow[t]{3}{*}{$\mathrm{x}_{1}$} & $\mathrm{y}_{1}$ & .110 & 1 & .110 & 11.629 & .001 & .029 \\
\hline & $\mathrm{y}_{2}$ & .010 & 1 & .010 & 20.537 & .000 & .050 \\
\hline & $\mathrm{y}_{3}$ & .001 & 1 & .001 & .142 & .707 & .000 \\
\hline \multirow[t]{3}{*}{$x_{2}$} & $\mathrm{y}_{1}$ & .970 & 1 & .970 & 102.128 & .000 & .207 \\
\hline & $\mathrm{y}_{2}$ & .008 & 1 & .008 & 18.154 & .000 & .044 \\
\hline & $\mathrm{y}_{3}$ & .004 & 1 & .004 & .860 & .354 & .002 \\
\hline \multirow[t]{3}{*}{$\operatorname{Inx}_{3}$} & $\mathrm{y}_{1}$ & .934 & 1 & .934 & 98.333 & .000 & .201 \\
\hline & $\mathrm{y}_{2}$ & .011 & 1 & .011 & 24.075 & .000 & .058 \\
\hline & $\mathrm{y}_{3}$ & .047 & 1 & .047 & 10.791 & .001 & .027 \\
\hline \multirow[t]{3}{*}{$\mathrm{x}_{1} * \mathrm{x}_{2} * \operatorname{In} \mathrm{x}_{3}$} & $\mathrm{y}_{1}$ & .049 & 1 & .049 & 5.125 & .024 & .013 \\
\hline & $\mathrm{y}_{2}$ & .001 & 1 & .001 & 1.389 & .239 & .004 \\
\hline & $\mathrm{y}_{3}$ & 4.34E-005 & 1 & 4.34E-005 & 0.10 & .921 & .000 \\
\hline \multirow[t]{3}{*}{ Error } & $\mathrm{y}_{1}$ & 3.724 & 392 & .009 & & & \\
\hline & $\mathrm{y}_{2}$ & .182 & 392 & .000 & & & \\
\hline & $\mathrm{y}_{3}$ & 1.723 & 392 & .004 & & & \\
\hline \multirow[t]{3}{*}{ Total } & $\mathrm{y}_{1}$ & 16.397 & 397 & & & & \\
\hline & $\mathrm{y}_{2}$ & .656 & 397 & & & & \\
\hline & $\mathrm{y}_{3}$ & 4.083 & 397 & & & & \\
\hline \multirow[t]{3}{*}{ Corrected Total } & $\mathrm{y}_{1}$ & 8.548 & 396 & & & & \\
\hline & $\mathrm{y}_{2}$ & .263 & 396 & & & & \\
\hline & $\mathrm{y}_{3}$ & 1.812 & 396 & & & & \\
\hline
\end{tabular}

From table (6), the researcher revealed that:

- The covariate Variables Standard deviation of Return On Equity $X_{1}$, Standard deviation of Return On Asset $\mathrm{X}_{2}$, natural logarithm of total asset $\ln \mathrm{X}_{3}$ and the interactions between $\mathrm{x}_{1} \mathrm{x}_{2}$ and $\ln \mathrm{x}_{3}$ explain (5-56.4\%) from total variation of dependent variables in terms of Return On Equity $\mathrm{Y}_{1}$, Return On Assets $\mathrm{Y}_{2}$, and Liquidity $\mathrm{Y}_{3}$.

- There is a significant effect of the covariate Variables in terms of $x_{1}, x_{2}$, and $\ln x_{3}$ on the dependent variables in terms of $\mathrm{y}_{1}$, and $\mathrm{y}_{2}$, at a significant level less than (0.001). 
1. Coefficient of determination $=.564$, adjusted coefficient of determination $=.560$

2. Coefficient of determination $=.309$, adjusted coefficient of determination $=.302$

3. Coefficient of determination $=.049$ adjusted of coefficient of determination $=.039$

From table (6), the researcher revealed that:

- The covariate Variables ST $\operatorname{ROE}\left(\mathrm{X}_{1)}, \mathrm{STROA}\left(\mathrm{X}_{2},\right)\right.$ natural logarithm of total assets $\left(\ln X_{3}\right)$ and the interactions between $\mathrm{x}_{1} \mathrm{x}_{2}$ and $\ln \mathrm{x}_{3}$ explain (5-56.4\%) from total variation of dependent variables in terms of $\operatorname{ROE}\left(\mathrm{Y}_{1}\right), \operatorname{ROA}\left(\mathrm{Y}_{2)}\right.$, and Liquidity $\mathrm{Y}_{3}$.

- There is a significant effect of the covariate Variables in terms of $X_{1}, X_{2}$, and $\ln _{3}$ on the dependent variables in terms of $\left(\mathrm{Y}_{1}\right)$, and $\left(\mathrm{Y}_{2}\right)$, at a significant level less than (0.001).

\subsection{Parameter Estimates}

According to the Multiple Regression model using ordinary least squares, the outcome from above table reports

1. There is a significantly positive linear relationship between $\left(\mathrm{X}_{1}\right)$ standard deviation of return on equity when $\beta=3.424819,\left(\mathrm{X}_{2}\right)$ standard deviation of return on asset when $\beta=2.62624996918$ when $P=(0.001)$ and natural logarithm of total assets when $\beta=$ 0.0340068336731 , with return on equity $\left(\mathrm{Y}_{1}\right)$ a probability $\geq(0.0259)$.

2. There is a significantly positive linear associated risk assessment measured by $\left(\mathrm{X}_{1}\right)$ standard deviation of return on equity when $\beta=0.909990054837,\left(\mathrm{X}_{2}\right)$ standard deviation of return on asset when $\beta=$ $(0.244324942181)$ and natural logarithm of total assets where $\mathrm{P}=0.00375909529112$ with return on asset, at a probability $=(0.001)$.

3. There is a significant positive linear relationship between $\left(\mathrm{X}_{1}\right)$ standard deviation of return on equity when $\beta=0.235872881803,\left(X_{2}\right)$ standard deviation of return on asset when $\beta=(0.163836007351)$ on liquidity; however, there is a negative relationship between and natural logarithm of total assets when $P$ $=(-0.00761283181416)$

The results of this study are consistent with theory of risk return, namely there is direct relationship between risk and return. That theory is known as efficient market theory, also in line with Lagat F. Kiprop [42] and Thitima Chaiyakul [27], who found a positive relationship between risk and financial performance but on contrary with $\mathrm{Yu}$ Luen Ma \& Yayuan Ren [30] which found a negative relationship between institutional ownership measured by (ratio of equity owned) and financial performance of insures during the financial crisis of 2008, but the relationship between institutional ownership with risk is positive, and the results consistent with asymmetric information approach Greenwald, Bruce and Stiglitz, Joseph E (43).

\subsection{The Coefficient of Determination}

The covariate independent Variables $\left(\mathrm{X}_{1}\right),\left(\mathrm{X}_{2}\right)$, and firm size $X_{3}$ the interactions between $X_{1}, X_{2}$ and $L N X_{3}$ explain $((5-56 \%))$ this ratio from total variation of $\mathrm{ROE}$ $\left(\mathrm{Y}_{1}\right)$, return on $\operatorname{assets}\left(\mathrm{Y}_{2}\right)$, and liquidity $\mathrm{y}_{3}$. As dependent variables

\subsection{F Test}

The reason for $\mathrm{F}$ test to examine the significance of the model in ability to predict, based on the results of the multivariate model the value of " $F$ test" is significant at $\geq$ $(0.05)$, then result indicates that covariate standard $\left(\mathrm{X}_{1}\right),\left(\mathrm{X}_{2}\right)$, and firm size $\mathrm{LN} \mathrm{X}_{3}$ the interactions between $\left(X_{1}\right)$ and $\left(X_{2}\right)$ have been effected on the level of dependent variables in terms of $\operatorname{ROE}\left(\mathrm{Y}_{1}\right), \operatorname{ROA}\left(\mathrm{y}_{2}\right)$, and liquidity y3.

\subsection{T-test}

There is a significant positive impact of the covariate Variables SDROE(X1), SD ROA $\left(\mathrm{X}_{2},\right)$ and firm size $\ln \mathrm{x}_{3}$ on the dependent variables return on equity $\left(\mathrm{Y}_{1}\right)$, and return on asset $\left(\mathrm{Y}_{2}\right)$, at a probability $\geq(0.001)$, however there is a significantly negative impact of interactions among $\left(\mathrm{X}_{1}\right),\left(\mathrm{X}_{2}\right)$ and $\operatorname{lnx}_{3}$ on the dependent variables $\left(Y_{1}\right) y_{1}$, where $P \geq(0.05)$. There is no significantly impact of covariate Variables in terms of $\left(\mathrm{X}_{1}\right),\left(\mathrm{X}_{2}\right)$, and interactions among $\left(\mathrm{X}_{1}\right),\left(\mathrm{X}_{2}\right)$ and $\ln \times 3$ on the dependent variable liquidity $\left(\mathrm{Y}_{3}\right)$, where $\mathrm{P} \leq 0.05$

There is a positively significant influence of the covariate Variables SDROE $\left(\mathrm{X}_{1}\right)$ and SDROA on asset $\left(\mathrm{X}_{2}\right)$ on the dependent variables return on equity $\left(\mathrm{Y}_{1}\right)$, and return on asset $\left(\mathrm{Y}_{2}\right)$, where $\mathrm{P} \geq(0.01)$, however there is a negatively significant influence of interactions between SDROE $\left(\mathrm{X}_{1}\right)$ and SD ROA $\left(\mathrm{X}_{2}\right)$ on the dependent variables in terms of $Y_{1}$, and $Y_{2}$, where $P \geq(0.001)$. , There is an insignificant influence of covariate Variables in terms of SD ROE $\left(\mathrm{X}_{1}\right)$, ST ROA $\left(\mathrm{X}_{2}\right)$, and the interactions between SD ROE $\left(\mathrm{X}_{1}\right)$ and SDROA $\left(\mathrm{X}_{2}\right)$ on the dependent variable liquidity $\left(\mathrm{Y}_{3}\right)$, where $\mathrm{p} \geq(0.05)$. 
Table 7. Analysis of regression to measure impact of the covariate on the dependent variables

\begin{tabular}{|c|c|c|c|c|c|}
\hline \multicolumn{6}{|c|}{$\begin{array}{l}\text { 1-regression analysis to examine impact of the covariate of } x_{1}, x_{2}, \ln x_{3} \text {, the interactions between } x_{1} x_{2} \text { and } \ln x_{2} \text { on the dependent variables in } \\
\text { terms of } y_{1}\end{array}$} \\
\hline Variable & Coefficient & Std. Error & t-Statistic & Prob. & VIF \\
\hline $\mathrm{X}_{1}$ & 3.074693 & 0.907362 & 3.388608 & $0.001 * * *$ & 4.156388 \\
\hline $\mathrm{X}_{2}$ & 2.626250 & 0.260569 & 10.07889 & $0.001 * * *$ & 4.417724 \\
\hline $\operatorname{Lnx}_{3}$ & 0.034007 & 0.003425 & 9.928236 & $0.001 * * *$ & 1.150120 \\
\hline $\mathrm{X}_{1} * \mathrm{x}_{2} * \ln \mathrm{x}_{3}$ & -2.135617 & 0.955094 & -2.236028 & $0.0259^{*}$ & 9.317182 \\
\hline $\mathrm{C}$ & -0.470354 & 0.047931 & -9.813089 & $0.001 * * *$ & -- \\
\hline \multicolumn{6}{|c|}{$\begin{array}{l}\mathrm{R}^{2}=56.4 \% \mathrm{~F} \text {-test }=127.1 \mathrm{Sig}=0.001 * * * \mathrm{AIC}=-1.81 \mathrm{SC}=-1.76 \mathrm{HQC}=-179 \mathrm{RMSE}=0.096 \mathrm{U}=0.25 \mathrm{DW}=1.84 \mathrm{JB}=99.2 \mathrm{SIG}=0.001 \mathrm{BG}=0.029 \\
\mathrm{SIG}=0.97 \text { Heteroskedasticity Test }: \mathrm{BPG} \text { F-test }=0.743 \mathrm{Sig}=0.563 \text { Ramsey RESET Test } \mathrm{F} \text { test }=0.984 \mathrm{Sig}=0.32\end{array}$} \\
\hline \multicolumn{6}{|c|}{$\mathrm{Y}_{1}=3.07469293978 * \mathrm{X}_{1}+2.62624996918 * \mathrm{X}_{2}+0.0340068336731 * \ln x_{3}-2.13561693439 * \mathrm{X}_{1} * \mathrm{X}_{2} * \ln \mathrm{x}_{3}-0.47035432778$} \\
\hline \multicolumn{6}{|c|}{$\begin{array}{l}\text { 2- regression analysis to examine the effect of the covariate } x_{1}, x_{2}, \ln x_{3} \text {, and the interactions between } x_{1} x_{2} \text { and } \ln x_{3} \text { on the dependent } \\
\text { variables in terms of } y_{2}\end{array}$} \\
\hline $\mathrm{X} 1$ & 0.909990 & 0.200493 & 4.538763 & $0.001 * * *$ & 4.156388 \\
\hline $\mathrm{X} 2$ & 0.244325 & 0.057576 & 4.243515 & $0.001 * * *$ & 4.417724 \\
\hline $\operatorname{Lnx} 3$ & 0.003759 & 0.000757 & 4.966729 & $0.001 * * *$ & 1.150120 \\
\hline $\mathrm{X} 1 * \mathrm{x} 2 * \ln x 3$ & -0.246495 & 0.211040 & -1.168002 & 0.2435 & 9.317182 \\
\hline $\mathrm{C}$ & -0.041982 & 0.010591 & -3.963933 & $0.001 * * *$ & -- \\
\hline \multicolumn{6}{|c|}{$\begin{array}{l}\mathrm{R}^{2}=31 \% \text { F-test }=44.1 \mathrm{Sig}=0.001, \mathrm{AIC}=-4.82 \mathrm{SC}=-4.77 \mathrm{HQC}=-4.80 \text { RMSE }=0.021 \mathrm{U}=0.28 \mathrm{DW}=1.63 \mathrm{JB}=2.72 \mathrm{SIG}=0.257 \mathrm{BG}=0.904 \\
\mathrm{SIG}=0.41 \text { Heteroskedasticity Test }: \mathrm{BPG} \text { F-test }=2.07 \mathrm{Sig}=0.084 \text { Ramsey RESET Test } \mathrm{F} \text { test }=3.7 \mathrm{Sig}=055\end{array}$} \\
\hline \multicolumn{6}{|c|}{$\mathrm{Y}_{2}=0.909990054837 * \mathrm{X}_{1}+0.244324942181 * \mathrm{X}_{2}+0.00375909529112 * \ln \mathrm{x}_{3}-0.246495039685 * \mathrm{X}_{1} * \mathrm{X}_{2} * \ln _{3}-0.0419821323686$} \\
\hline \multicolumn{6}{|c|}{$\begin{array}{l}\text { 3- regression analysis to examine effect of the covariate } x_{1}, x_{2}, \ln x_{3} \text {, the interactions between } x_{1} x_{2} \text { and } \ln x_{3} \text { on the dependent variables in } \\
\text { terms of } y_{3}\end{array}$} \\
\hline $\mathrm{X}_{1}$ & 0.235873 & 0.617416 & 0.382032 & 0.7026 & 4.156388 \\
\hline $\mathrm{X}_{2}$ & 0.163836 & 0.177305 & 0.924035 & 0.3560 & 4.417724 \\
\hline $\mathrm{Lnx}_{3}$ & -0.007613 & 0.002331 & -3.266290 & 0.0012 & 1.150120 \\
\hline $\mathrm{X}_{1} * \mathrm{x}_{2} * \ln \mathrm{x}_{3}$ & 0.064782 & 0.649895 & 0.099681 & 0.9206 & 9.317182 \\
\hline $\mathrm{C}$ & 0.162210 & 0.032615 & 4.973472 & $0.001 * * *$ & -- \\
\hline \multicolumn{6}{|c|}{$\begin{array}{l}\mathrm{R}^{2}=4.9 \% \text { F-test }=5.04 \mathrm{sig}=0.001 * * * \mathrm{AIC}=-2.58 \mathrm{SC}=-2.53 \mathrm{HQC}=-2.57 \mathrm{RMSE}=0.066 \mathrm{U}=0.37 \mathrm{DW}=1.75 \mathrm{JB}=50.2 \mathrm{SIG}=0.001 \mathrm{BG}=2.52 \\
\mathrm{SIG}=0.06 \text { Heteroskedasticity Test }: \text { BPG F-test }=1.59 \mathrm{Sig}=0.17 \text { Ramsey RESET Test } \mathrm{F} \text { test }=3.82 \mathrm{Sig}=0.051\end{array}$} \\
\hline \multicolumn{6}{|c|}{$\mathrm{Y}_{3}=0.235872881803 * \mathrm{X}_{1}+0.163836007351 * \mathrm{X}_{2}-0.00761283181416 * \mathrm{LNX}_{3}+0.0647820724583 * \mathrm{X}_{1} * \mathrm{X}_{2} * \mathrm{LNX}_{3}+0.162209604044$} \\
\hline
\end{tabular}

\subsection{VIF Values}

Variance inflation factors are statistically used to measure multicollinearity. Multicollinearity is a problem when variance inflation factors exceed 10 . Other viewpoints consider the value of the variance inflation factors should not exceed 4 or 5 . From the table above, the value of VIP $\geq 4$, based on this result there is no multicollinearity problem.

\subsection{The Jarque-Bera Test}

Since the significance value of the Jarque-Bera test statistic $(<0.05)$, null hypothesis is not accepted $\left(\mathrm{H}_{0}\right)$ : Errors are normally distributed.

Since the coefficient of Pearson skewness is $\geq(1)$ or greater than or equal $(-1)$, this result elucidated that data is not significantly skewed.

\subsection{Theil's Inequality Coefficient $U$}

This test is used to measure the accuracy of the estimates of the fixed effects model. The range of Theil's inequality coefficient $U$ ( 0 to 1$)$, where zero indicates a perfect fit. Since value ranges between 0.25 and 0.37 ), this result indicates the goodness of fit of the model, at a percent of $\leq(72 \%)$ the first two models.

\subsection{The Durbin-Watson Test Statistic}

This test to investigate the interaction between risk assessment and financial performance in insurance firms in Egypt, when Non-autocorrelation when a value near 2; when a value toward 0 refers to positive autocorrelation; while a value toward 4 refers to a negative autocorrelation., the null hypothesis is accepted Since the test statistic value (1.63-1.84) was greater than DU 


\subsection{Breusch-Godfrey Serial Correlation LM Test}

The BG significance value is $(\geq 0.05)$, then the null hypothesis $\left(\mathrm{H}_{0}\right)$ is accepted: there is no serial correlation up to lag order P (2)

\subsection{Heteroskedasticity Test}

It is revealed that a level of significance for the tests: F-statistic, Obs * R-squared, Scaled explained $\mathrm{SS}$ is $\leq$ $(0.05)$, which indicates the acceptance of the null hypothesis which provides for the Homoskedasticity of error term.

\subsection{Ramsey RESET Test}

Since significance value of T-statistic 'F-statistic ، Likelihood ratio test statistic $(\geq 0.05)$ then the null hypothesis $\left(\mathrm{H}_{0}\right)$ is reject: The functional form is correct. No variable is omitted.

\subsection{Recursive Estimation}

Figure 1 illustrate CUSUM test. The result shows the instability of parameters because cumulative sum appears outside area between two critical lines, according to cumulative sum of the recursive residual this option illustrates cumulative sum together with $5 \%$

\subsection{Leverage}

Leverage score calculated as $(\mathrm{L}+1) / \mathrm{N}$ where $\mathrm{L}$ is measured $\mathrm{X}$ !, $\mathrm{X} 2$ and $\mathrm{X} 3$ as independent variables using in the model where $\mathrm{N}$ is observations. Leverage scores 2 to 3 times this value. This means Observations with high leverage. All centered leverage values are less than leverage score $3(\mathrm{~L}+1) / \mathrm{N}$, will pull the regression line towards it when observation with high leverage.

\subsection{Cooks Distance}

All cooks distances are presented below the threshold index $4 / n$.

\subsection{Mahalanobis $D^{2}$}

The significance value of the MahalanobisD ${ }^{2}$ test statistic $(\geq 0.001)$. Based on this result, null hypothesis is (H0): data is normally multivariate distributed, and regression model does not contain multivariate outliers.

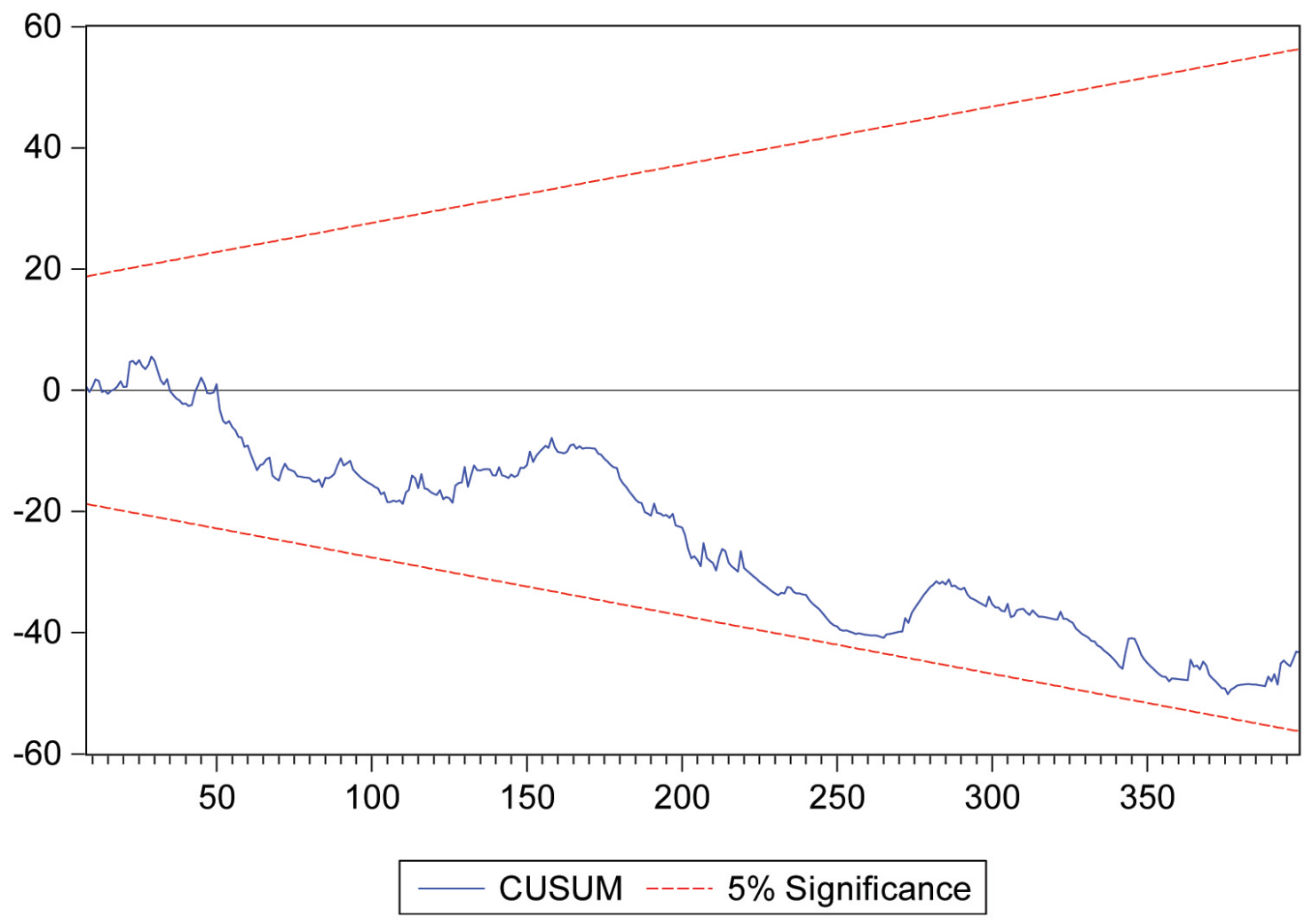

Figure 1. Cumulative Sum Control Chart 
The above figure illustrate CUSUM test according to cumulative sum of the recursive residual. This option plots the cumulative sum together with the $5 \%$ critical lines. The result shows the parameter instability if the cumulative sum goes outside area between two critical lines.

\section{Conclusions}

This study used general linear multivariate analysis and descriptive statistics to investigate the relationship between risk assessments on financial performance of insurance sector in Egypt ; data was collected form financial reporting (balance sheets - income statements) which is issued by the Financial Regulatory Authority in Egypt over the period 1999- 2019, whereas the sample included nineteen Egyptian insurance companies which were selected according to the availability of data during the study period. The study findings indicate that:

1. There is a significant positive linear relationship between standard deviation of return on equity when $\beta=3.424819$, and standard deviation of return on asset when $\beta=2.62624996918$ when $P=(0.001)$, and natural logarithm of total assets when $\beta=$ 0.0340068336731 , with return on equity, at a probability $\geq(0.0259)$.

2. There are significant positive linear relationships between standard deviation of return on equity when $\beta=0.909990054837$, standard deviation of return on asset when $\beta=(0.244324942181)$, and natural logarithm of total assets where $\mathrm{P}=0.00375909529112$ on return on asset, at a probability $=(0.001)$.

3. There are significant positive linear relationships between standard deviation of return on equity when $\beta=0.235872881803$, standard deviation of return on asset when $\beta=(0.163836007351)$ on liquidity; however, there is a negative relationship between and natural logarithm of total assets when $\mathrm{P}=$ $(-0.00761283181416)$.

However, this study is in line with asymmetry information approach which was developed by Greenwald, Bruce and Stiglitz, Joseph E (43) who have proved that as a consequence firms will act in a risk averse manner, .

\section{REFERENCES}

[1] Ahmad Abdelrahim, Suliman Raji weshah \& Mohammad Aldahiyat, Liquidity and Solvency Management and its Impact on Financial Performance: Empirical Evidence from Jordan, Journal of Asian Finance, Economics and Business Vol 8 No 5, 2021 doi:10.13106/jafeb.2021.vol8.no5.0135.

[2] Alalade S. Yimka, Agbatogun Taofeekm Cole Abimbola \& Adekunle Olusegun, Credit risk management and financial performance of selected commercial banks in Nigeria, Journal of Economic \& Financial Studies, Vol. 03, No. 01, 2015, DOI:10.18533/jefs.v3i01.73.
[3] Arif A. Wani \& Showket A. Dar, Relationship between Financial Risk and Financial Performance: An Insight of Indian Insurance Industry, International Journal of Science and Research, Vol 4 Issue 11, 2015, https://www.researchgate.net/publication/339875460

[4] Bimbin P. Chepkemoi, Steve Ndung's \& Julius Kahuthia, Market Risk and Financial Performance of Listed Non Bank Financial Institute in Kenya, International Academic Journal of Economics and Finance, Vol 3, Issue 3, 2019, https://www.researchgate.net/publication/350753915.

[5] Bimo A, Tejo1\& Dewi Hanggraeni, The Effects of Credit Risk and Financial Performance to Financial Distress Prediction of Listed Banks in Indonesia, Advances in Economics, Business and Management Research, vol.160, 2020, http://dx.doi.org/10.2991/aebmr.k.201222.022.

[6] Claudia Champagne, Frank Coggins \& Stephane Chretien, Effects of pension fund freezing on firm performance and risk, Canadian Journal of Administrative Sciences, Vol 34: 306-320, 2017. DOI: 10.1002/CJAS.1338.

[7] Ghulam Saghir \& E. Tabassam C, Risk Management \& Financial Performance of Commercial Banks in Pakistan, The Lahore Journal of Business, Vol 9 issue 1, 2020, DOI: 10.35536/ljb.2020.v9.i1.a4

[8] Ibrahim M. Fali \& Lateef Olumide M., Financial Risk analysis and Financial Performance of listed Insurance Companies in Nigeria, European Journal of Business and Management Vol.12, No.12, 2020 DOI: 10.7176/EJBM/12-12-13.

[9] Jean B. Harelimana, the Role of Risk Management on Financial Performance of Banking Institutions in Rwanda, Business and Economics Journal, Vol 8 issue 1 2017, DOI: 10.4172/2151-6219.1000284

[10] Jing Ai, Vickie Bajtelsmit \& Tianyang Wand, The Combined Effect of Enterprise Risk Management and Diversification on Property and Casualty Insurer Performance, The Journal of Risk and Insurance. Vol. 85, No. 2, 513-543, 2016. DOI: 10.1111/jori.12166.

[11] Jowhar Massoudie, An Empirical Investigation of Financial Risk Management on Financial Performance of Commercial Banks, International Journal of Technical Research \& Science, Vol. V Issue VIII, 2020, doi:/10.30780/IJTRS.v05I08.

[12] Kokobe SA, \& Gemechu D, Risk Management Techniques and Financial Performance of Insurance Companies. International Journal of Account Research vol 4:127, 2016. doi:10.4172/ijar.1000127.

[13] L. Paige Fields, Manu Gupta \& Puneet Prakash, Risk Taking and Performance of Public Insures: an International Comparison, The Journal of Risk and Insurance, Vol. 79, No. 4, 931-962, 2012, DOI: 10.1111/j.1539-6975.2012.014 79.x .

[14] Lemaa B, Zeleke \& Sindhu, Effect of Risk Management on Banks Financial Performances: EVIDENCES FROM Ethiopian Commercial Banks, International Journal of Management, Vol 12, Issue 3, 2021, DOI: 10.34218/IJM.12.3.2021.013

[15] Leonora H. Rudhani \& Driton Balaj, The Effect of Liquidity Risk on Financial performance, Advances in Business-Related Scientific Research Journal, Volume 10, No. 2, 2019. 
[16] Michael Adusei, The liquidity risk-financial performance nexus: Evidence from hybrid financial institutions, Managerial and decision economics vol 42 issue 3, 2021, https://doi.org/10.1002/mde.3357

[17] Nasratullah Noori, The Effects of Financial Risks Management on Financial Performance of Commercial Banks in Malaysia, 2021, http://dx.doi.org/10.13140/RG.2. 2.21472.61445.

[18] Nicoleta B. -Misu, Mara Madaleno \& Vasile Ilie, Analysis of Risk Factors Affecting Firms' Financial Performance-Support for Managerial Decision-Making, sustainability Vol 11 issue (18), 2019. http://dx.doi.org/10.3390/su11184838Olayinka

[19] Olayinka Erin, Omololu Bamigboye, Jonah Arumona, Risk Governance and Financial Performance: an Empirical Analysis, Business: Theory and Practice, Vol 21 Issue 2, 2020. https://doi.org/10.3846/btp.2020.10850.

[20] Peter Karugu Kahihu, David Muturi Wachira \& Stephen Makau Muathe, Managing market risk for financial performance: experience from micro finance institution in Kenya, Journal of Financial Regulation and Compliance, 2021, http://dx.doi.org/10.1108/JFRC-02-2021-0014

[21] Ramazan Ekinci1\& Gulden Poyraz, The Effect of Credit Risk on Financial Performance of Deposit Banks In Turkey, Procedia Computer Science 158, 2019. https://doi.org/10.1 016/j.procs.2019.09.139

[22] Ravi Prakash Sharma P., the impact of credit risk management on financial performance of commercial banks in Nepal, International Journal of Arts and Commerce Vol. 1 No. 5, 2012.https://www.researchgate.net/publication/27 3383001

[23] Robert Mironga Siriba, Credit Risk and Financial Performance of Commercial Banks in Kenya, international journal of science and research Publications, Vol 10, Issue 4, 2020.

http://dx.doi.org/10.29322/IJSRP.10.04.2020.p10051.

[24] Samuel Gameli Gadzo, Holy Kwabla Kportorgbi \& John Gartchie Gatsi, Credit risk and operational risk on financial performance of universal banks in Ghana: A partial least squared structural equation model (PLS SEM) approach, Vol7, 2019: 1589406.https://doi.org/10.1080/23322039.20 19.1589406

[25] Suleiman A. S. Aruwa \& Abdullahi O. Musa, Risk components and the Financial Performance of Deposit Money Bank in Nigeria, international journal of social sciences and entrepreneurship, Vol.1, Issue 11, 2014.

[26] Sylvester Senyo Horvey \& Jacob Ankamah, Enterprise risk management and firm performance: Empirical evidence from Ghana equity market, 2020, https://doi.org/10.1080/2 3322039.2020 .1840102

[27] Thitima Chaiyakul, Bankruptcy Risk and Financial Performance of Companies Listed on the Stock Exchange of Thailand, International Journal of Financial Research, Vol. 12, No. 4, 2012. https://doi.org/10.5430/ijfr.v12n4p78.

[28] Walter Gontarek \&Yacine, Belghitar, Risk governance: Examining its impact upon bank performance and risk-taking, financial markets institutions \&instilments Vol 27 issue 5, 2018. DOI: 10.1111/fmii.12103.

[29] Yu-Chuan Chen, Yung-Ho Chiu \& Ching-Jen Chiu, the performance evaluation of banks considering risk: an application of undesirable relation network DEA, INTERNATIONAL TRANSACTIONS IN OPERATIONAL RESEARCH, Vol 27 issue 2, 2020. https://doi.org/10.1111/itor.12446 .

[30] YuLuen Ma \& Yayuan Ren, Insurer risk and performance before, during, and after the 2008 financial crisis: The role of monitoring institutional ownership, journal of risk insurance, Vol 88 issue 2, 2020, DOI: 10.1111/jori.12323.

[31] Saleh Mohamed Eladly, Sources Allocation on Risk Performance in Insurance Companies, Journal of Management and Strategy, vol.12, NO. 3, 2021, DOI:10.5430/jms.v12n3p32

[32] Dejan S. Drljača, Risk Assessment through Matrix Model in Insurance Companies, http://scindeks.ceon.rs/JournalDetail s.aspx?issn=1820-6859 2016, vol. 10, br. 2, str. 43-65 http://dx.doi.org/10.5937\%2Fposeko10-12637

[33] Fei Ma, Risk Analysis of Insurance companies Fund application in China, International Journal of Innovative Research in Information Security Issue 8, Volume 2, 2015.

[34] Ferren Alwie \& Mila Novitab \& Suci Fratama Sari, Risk Measurement for Insurance Sector with Credible Tail Value-at-Risk, Cite as: AIP Conference Proceedings 2184, 050039, 2019; https://doi.org/10.1063/1.5136427.

[35] Gene C. Lai, Lin-Yhi Chou \& Lih Ru Chen, the Impact of Organizational Structure and Business Strategy on Performance and Risk-Taking Behavior in Insurance Industry, Applied Finance and Accounting Vol. 1, No. 2, 2015, http://dx.doi.org/10.11114/afa.vli2.911.

[36] J. David Cummins \& David W. Sommer Capital and risk in property-liability insurance markets, Journal of Banking \& Finance 20, 1996, 1069-1092, https://doi.org/10.1016/0378 $-4266(95) 00044-5$.

[37] Jekaterina Kuzmina, Gaida Pettere \& Irina Voranova, Conditional Risk Measure Modeling for Latvian Insurance Companies, Perspectives of Innovations, Economics \& Business, Volume 3, 2009, http://dx.doi.org/10.15208/pieb .2009 .56 .

[38] Ognjen Vukovic Operational Risk Modelling in Insurance and Banking, Journal of Financial Risk Management, 2015, 4, 111-123 http://dx.doi.org/10.4236/jfrm.2015.43010.

[39] Zlata Djuric, Collective Risk Model in Non -Life Insurance, Economic Horizons, May - August 2013, Vol. 15, NO 2, P 167 - 175, doi: 10.5937/ekonhor1302163D.

[40] Richard D, MacMinn, On Corporate Risk Management and Insurance, Journal of Risk \& Insurance Vol 1 NO (1)2005 http://dx.doi.org/10.2202/2153-3792.1005.

[41] Selim Mankai \& Aymen Belgacen, Interactions between Risk Taking, Capital and Reinsurance for Property Liability Insurance Firms, the Journal of Risk and Insurance Vol. 83 NO. 4, 2015. DOI: 10.1111/jori.12080

[42] Lagat F. Kiprop, Effect of Risk Identification on Performance of Financial Institutions, International Journal of Business Strategy, Vol.2, Issue 1 No.5, pp. 75- 87, 2017.

[43] Greenwald, Bruce and Stiglitz, Joseph E., Asymmetric Information and the New Theory of the Firm: Financial Constraints and Risk Behavior (1990). NBER Working Paper No. w3359, Available at SSRN: https://ssrn.com/abstract=22666 